University of Nebraska - Lincoln

DigitalCommons@University of Nebraska - Lincoln

$11-4-2016$

\title{
Sandhill Crane Roost Selection, Human Disturbance, and Forage Resources
}

\author{
Aaron T. Pearse \\ Northern Prairie Wildlife Research Center, apearse@usgs.gov \\ Gary L. Krapu \\ Northern Prairie Wildlife Research Center \\ David A. Brandt \\ Northern Prairie Wildlife Research Center
}

Follow this and additional works at: https://digitalcommons.unl.edu/usgsnpwrc

Part of the Animal Sciences Commons, Behavior and Ethology Commons, Biodiversity Commons, Environmental Policy Commons, Recreation, Parks and Tourism Administration Commons, and the Terrestrial and Aquatic Ecology Commons

Pearse, Aaron T.; Krapu, Gary L.; and Brandt, David A., "Sandhill Crane Roost Selection, Human Disturbance, and Forage Resources" (2016). USGS Northern Prairie Wildlife Research Center. 424. https://digitalcommons.unl.edu/usgsnpwrc/424

This Article is brought to you for free and open access by the US Geological Survey at DigitalCommons@University of Nebraska - Lincoln. It has been accepted for inclusion in USGS Northern Prairie Wildlife Research Center by an authorized administrator of DigitalCommons@University of Nebraska - Lincoln. 
Research Article

\title{
Sandhill Crane Roost Selection, Human Disturbance, and Forage Resources
}

\author{
AARON T. PEARSE, ${ }^{1}$ U.S. Geological Survey, Northern Prairie Wildife Research Center, Jamestown, ND 58401, USA \\ GARY L. KRAPU, U.S. Geological Survey, Northern Prairie Wildlife Research Center, Jamestown, ND 58401, USA \\ DAVID A. BRANDT, U.S. Geological Survey, Northern Prairie Wildife Research Center, Jamestown, ND 58401, USA
}

\begin{abstract}
Sites used for roosting represent a key habitat requirement for many species of birds because availability and quality of roost sites can influence individual fitness. Birds select roost sites based on numerous factors, requirements, and motivations, and selection of roosts can be dynamic in time and space because of various ecological and environmental influences. For sandhill cranes (Antigone canadensis) at their main springstaging area along the Platte River in south-central Nebraska, USA, past investigations of roosting cranes focused on physical channel characteristics related to perceived security as motivating roost distribution. We used 6,310 roost sites selected by 313 sandhill cranes over 5 spring migration seasons (2003-2007) to quantify resource selection functions of roost sites on the central Platte River using a discrete choice analysis. Sandhill cranes generally showed stronger selection for wider channels with shorter bank vegetation situated farther from potential human disturbance features such as roads, bridges, and dwellings. Furthermore, selection for roost sites with preferable physical characteristics (wide channels with short bank vegetation) was more resilient to nearby disturbance features than more narrow channels with taller bank vegetation. The amount of cornfields surrounding sandhill crane roost sites positively influenced relative probability of use but only for more narrow channels $<100 \mathrm{~m}$ and those with shorter bank vegetation. We confirmed key resource features that sandhill cranes selected at river channels along the Platte River, and after incorporating spatial variation due to human disturbance, our understanding of roost site selection was more robust, providing insights on how disturbance may interact with physical habitat features. Managers can use information on roost-site selection when developing plans to increase probability of crane use at existing roost sites and to identify new areas for potential use if existing sites become limited. (c) 2017 The Wildlife Society.
\end{abstract}

KEY WORDS disturbance, habitat selection, Nebraska, nocturnal roost selection, Platte River, sandhill crane.

Identifying habitat characteristics that species select provides a useful framework for identifying and focusing management and restoration efforts. Habitat selection studies help establish where a species finds resources needed to meet daily and seasonal physiological, nutritional, and behavioral requirements (Morris 2003). Selection of habitats or resources can be dynamic in time and space, and this variability may be mediated by numerous factors including weather, disturbance, predator activity, and population density (McLoughlin et al. 2010). Recognizing to what extent external factors influence habitat selection can provide greater insight into resource selection, reveal tradeoffs that may exist, and provide an expanded view of the variety of habitats needed by animals as they encounter fluctuating conditions and complex situations.

Roost sites represent a major habitat need for birds, and for certain species, roost sites can be highly specialized and

Received: 21 June 2016; Accepted: 4 November 2016

${ }^{1}$ E-mail: apearse@usgs.gov relatively scarce (Lambertucci and Ruggiero 2013). In these situations, it may be particularly useful to have a detailed understanding of multiple factors that influence roost-site use because of the potential difficulty in restoring or replicating roost sites once lost. Availability and quality of rest or roost sites can influence individual fitness (Sunde et al. 2003, Bock et al. 2013); thus, management directed at protecting or enhancing such sites can represent key conservation actions.

The central Platte River Valley represents a key midlatitude stopover location where about $80 \%$ of the midcontinent sandhill crane (Antigone canadensis) population gains lipids that they will use for continued migration and reproduction at northern breeding sites (Krapu et al. 1985, 2014). During their stay, sandhill cranes primarily use flowing river channels as nocturnal roost sites (Lewis 1976, Sparling and Krapu 1994). Since the 1950s, mid-continent sandhill cranes have progressively abandoned large portions of the Platte River, even with increased population abundance (Faanes and LeValley 1993, Krapu et al. 2014). Substantial changes to river characteristics, including reduced river flow and encroachment of woody vegetation 
have been implicated, suggesting that channel characteristics influence distribution of sandhill cranes along the Platte River (U.S. Fish and Wildlife Service 1981, Krapu et al. 2014).

Birds select roost sites based on numerous factors, requirements, and motivations. Roost sites suitable for sandhill cranes have been characterized as river reaches with a wide channel and short bank vegetation structure with little visual obstruction (Krapu et al. 1984, Folk and Tacha 1990). These general characteristics imply that cranes primarily select roost sites based on perceived security, because wide channels with short bank vegetation provide opportunity for cranes to detect predators. Disturbances influence habitat use and selection in birds, including at roost sites of sandhill cranes and other birds (Krapu et al. 1984, Pfister et al. 1992, Peters and Otis 2007). Other factors also may motivate roost selection yet have received less attention in roosting sandhill cranes. Flying long distances from roosts to foraging sites can be energetically expensive; thus, selecting nocturnal roosts closer to foraging sites signifies an energy savings (Cox and Afton 1996, Dias et al. 2006, Anteau et al. 2011, Chudzińska et al. 2015). Roost use also may be affected by weather conditions; birds seek sites that may provide thermal shelter during adverse environmental conditions (Buttemer 1985, Hiller and Guthery 2005, Rogers et al. 2006).

Various ecological and environmental characteristics can affect temporal and spatial variation in habitat selection (McLoughlin et al. 2010); thus, investigating and understanding this variation may provide greater insight into use of roost sites and allow for conservation strategies that target an array of roost characteristics that cranes may select. Currently, the United States Fish and Wildlife Service and conservation organizations fund annual maintenance activities to provide sandhill cranes and other species places to roost during spring migration (Kessler et al. 2013). These organizations also are interested in development of new roost sites necessary for future sandhill crane population management. Our objectives were to provide a contemporary analysis of nocturnal roost selection for sandhill cranes staging along the Platte River and explore variation in selection for previously established characteristics of roost sites. In addition, we highlight the use of Light Detection and Ranging (Lidar) data to quantify vegetation height along the riverbank and how it influenced roost site selection.

\section{STUDY AREA}

We studied sandhill cranes during late winter and early spring (Feb-Apr) 2003-2007 along the Big Bend Reach of the Platte River between Grand Island and Kearney, Nebraska, USA (Fig. 1). This region is the major springstaging area for the mid-continent population of sandhill cranes (Krapu et al. 2014). The Platte River is a braided river with channels that are generally shallow and characterized by numerous emergent and submerged sandbars that provide roost habitat for $>500,000$ sandhill cranes (U.S. Fish and Wildlife Service 1981, Krapu et al. 2014). During late winter and early spring, the region was used by other migratory birds such as Canada goose (Branta canadensis), snow goose (Chen caerulescens), mallard (Anas platyrhynchos), and northern pintail (Anas acuta). The central Platte River resides in the humid continental climate zone and average minimum and maximum daily temperatures in the region during the months of study ranged from $-2.5^{\circ} \mathrm{C}$ to $-1.0^{\circ} \mathrm{C}$ and $11.0^{\circ} \mathrm{C}$ to $13.5^{\circ} \mathrm{C}$, respectively. Total precipitation during February-April was variable and ranged from $9.9 \mathrm{~cm}$ to $17.8 \mathrm{~cm}$, averaging $13.2 \mathrm{~cm}$. Dominant vegetation types within the central Platte River Valley are cropland, lowland grassland, subirrigated wet meadow, upland grassland, riparian forest, and shrubland. During our study, croplands were planted primarily to corn and soybeans with limited amounts of wheat, sorghum, and alfalfa (Pearse et al. 2010). Native lowland grasslands were dominated by big bluestem (Andropogon gerardii), switch-grass (Panicum virgatum), Indiangrass (Sorghastrum nutans), and sedges (Carex spp.). Dominant upland species included big bluestem, blue grama (Bouteloua gracilis), buffalograss (Bouteloua dactyloides), and little bluestem (Schizachyrium scoparium). Dominant species in riparian forests and shrublands included eastern cottonwood (Populus deltoides), eastern red cedar (Juniperus virginiana), green ash (Fraxinus pennsylvanica), roughleaved dogwood (Cornus drummondii), sandbar willow (Salix exigua), and silver buffaloberry (Shepherdia argentea; U.S. Fish and Wildlife Service 1981). Cranes generally use river channels as nocturnal roost sites, nearby cornfields to feed, and grasslands mainly to feed on invertebrates (Krapu et al. 1982, Reinecke and Krapu 1986). Water of the Platte River was used for irrigation of cultivated crops (largely corn and soybeans) and for generation of electricity by powering hydroelectric generators.

\section{METHODS}

\section{Field Data Collection}

During late February and early April 2003-2006, we used rocket-propelled nets and taxidermy-mounted decoys (Wheeler and Lewis 1972) to capture sandhill cranes at 51 sites in the central Platte River Valley (Krapu et al. 2014). We marked 1-4 adult cranes from each capture event. If marking multiple cranes, we chose birds from opposite ends of the net to limit the chance of sampling both members of a mated pair. We used a 2-piece leg band (Haggie Engraving, Crumpton, MD, USA) to attach a very high frequency (VHF) transmitter (Advanced Telemetry Systems, Isanti, MN, USA) to the left leg of randomly selected cranes. Transmitters and leg bands weighed approximately 60-65 g, representing $1-2 \%$ of body weight of marked birds. To extend battery life and facilitate tracking of individual cranes for several years, the manufacturer programmed transmitters to cycle between active (mid-Feb-mid-Apr) and latent periods. To maintain potential group and family bonds, we released most captured birds (marked and unmarked) within 30 minutes (range $=15-60 \mathrm{~min}$ ) of capture. Capture and marking procedures conformed to recommendations of the American Ornithologists' Union (Gaunt et al. 1999) and followed the protocol contained in Study Plan 169.02, which was approved on 13 July 1998 by the Chairman of the 


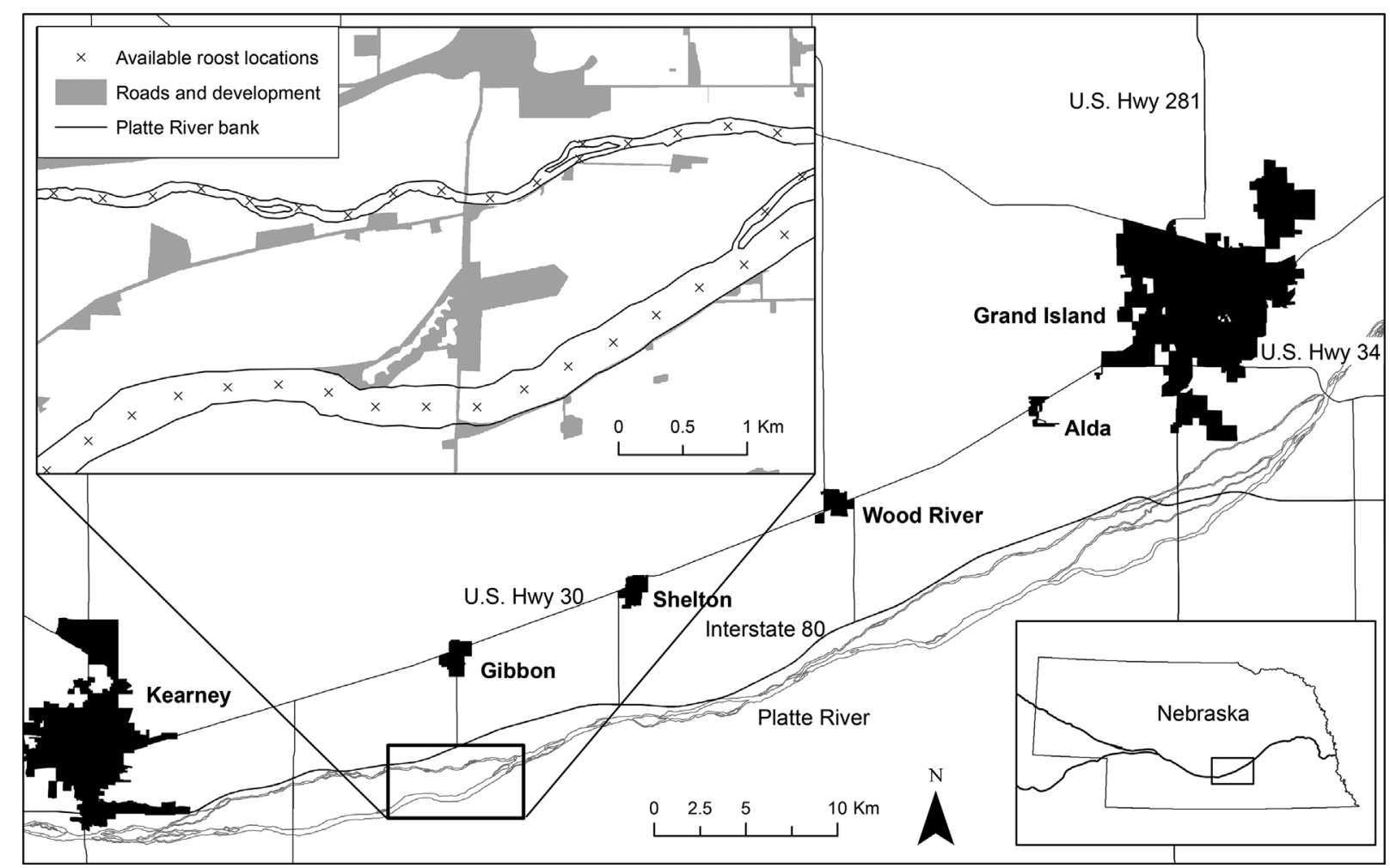

Figure 1. Sandhill cranes selected roost sites at the Platte River, Nebraska, USA, during spring migrations 2003-2006. For analyses, we partitioned river channels into 400-m segments as potential roost locations between Kearney and Grand Island, Nebraska (centroids identified by X). Primary characteristics of roost sites included channel width, bank vegetation height, and distance to human disturbances, including roads, bridges, and developed areas.

Animal Care and Use Committee at Northern Prairie Wildlife Research Center.

We used vehicles equipped with radio-receivers to search the central Platte River Valley for radio-marked cranes each evening from mid-February to mid-April 2003-2007. Technicians searched the entire study area during evenings (2200-0200) by listening for signals of all potentially active transmitters along roads parallel to the Platte River and stopping at river bridges (Fig. 1). For newly marked birds, we initiated monitoring on the fourth day following capture to allow for recovery from stress of capture and adjustment to transmitter attachment. After detecting a bird, we used standard null-peak systems and Locate II software (Pacer, Truro, Nova Scotia, Canada) to estimate nocturnal roost locations by triangulation. We used software to inspect estimated locations calculated via triangulation and associated error polygons (i.e., area surrounding a location that provided a measure of precision by which the location was estimated). The maximum size of error polygons used in this study was 19 ha. Before arrival of cranes each season, we evaluated telemetry receiving systems and operators (Krapu et al. 2014).

\section{Study Design and Covariates}

We investigated roost site selection by comparing sites used with those available to sandhill cranes using a resource selection function approach (Manly et al. 2002). Initially, we identified channels of the Platte River that were active (i.e., had flowing water) and were $\geq 15 \mathrm{~m}$ wide, assuming that they could be potentially available as crane roosts and thus excluding places that would have little chance to be crane roosts. We divided these channels into 400-m segments between bridges crossing the river south of Kearney, Nebraska, and Highway 34 near Grand Island, Nebraska (Fig. 1). We collapsed nocturnal roost locations derived from VHF telemetry to these segments for further analyses. Error polygons for roost sites from triangulation of radio-marked birds generally corresponded with radii less than a single segment's width (95th percentile $=10$ ha; $180-\mathrm{m}$ radius), which provided confidence that triangulated locations were within channel segments. For each roost location, we randomly selected 20 segments to characterize available roosts from all potential segments within $5.7 \mathrm{~km}$ of the used location, because cranes moved this average distance between subsequent nights (Krapu et al. 2014). Thus, a random selection of locations within this distance represented a choice set of roosts that a crane might have chosen on a particular night (Arthur et al. 1996, Compton et al. 2002).

We identified the active river channel by updating preexisting data to reflect spring 2005 conditions using aerial imagery and documented management activities (e.g., removal of woody vegetation) that had been recently applied. We chose 2005 because it represented a midpoint in time over which we collected roost locations. We estimated average width (m) of river channels for each 400-m segment by first constructing channel midlines for all portions of the active channel that were not impeded by islands with established vegetation greater than $3 \mathrm{~m}$ tall. Where vegetated 
islands existed in the active channel, we created separate midlines for each channel (Fig. 1). We then measured distances perpendicular to midlines at $10-\mathrm{m}$ intervals from bank to bank. Within each segment a mean of all bank-tobank values provided a representation of the segment's channel width.

We characterized bank vegetation height for each channel segment using Lidar point-cloud data from 2 acquisitions along the central Platte River. An August 2006 acquisition, flown at a nominal post-spacing of approximately 2 points $/ \mathrm{m}^{2}$, did not completely cover the area of interest. Thus, we used supplemental data from an October 2009 acquisition, which was flown at an average nominal postspacing of 0.7 points $/ \mathrm{m}^{2}$. Lidar vendors initially classified the point-cloud as ground and non-ground points with priority given to providing adequate ground points to derive a highresolution digital elevation model. This processing was not adequate for deriving riparian forest canopy; thus, we reprocessed Lidar data using the virtual de-foresting algorithm of Haugerud and Harding (2001) as a macro program within SAS (SAS Institute, Cary, NC, USA). We visually digitized human structures (e.g., houses, grain bins) by examining first-return Lidar intensity images and removed these structures from canopy closure estimates. Trees were fully leafed (leaf-on) when Lidar data were obtained in August, whereas deciduous trees had already dropped their leaves (leaf-off) when the October Lidar data were collected; thus, we calibrated the August acquisition to October conditions. Using area of overlap between the 2 acquisitions, we regressed October canopy closure estimates with those from August and then back-calculated August estimates to represent leaf-off conditions. We did this recalibration because leaf-off conditions better reflected the canopy when cranes arrive on the Platte River during spring migration. In using both acquisitions, we had to assume that vegetation conditions did not change appreciably between years. To compute vegetation height metrics, we first gridded acquisition areas into $3 \times 3-\mathrm{m}$ cells. Within each cell we calculated height above ground of each Lidar point and binned these values into $1-\mathrm{m}$ vertical categories. We identified cells within $50 \mathrm{~m}$ of channel banks and summarized all Lidar data to derive the average maximum height of vegetation along active channel banks associated with each 400-m river reach.

We calculated distance between used and available roost sites and potential anthropogenic disturbance features. To identify disturbances, we used a land cover classification of the region developed from data collected during 2005 (Brei et al. 2008). We calculated the distance from the center of each river segment to areas identified in the development land cover category, which included roads, bridges, and buildings (Fig. 1). We also determined percentage of cultivated corn surrounding potential roost sites. We created buffers surrounding each site with a radius of $2 \mathrm{~km}(1,256 \mathrm{ha})$ because this distance represented the average distance cranes traveled to cornfields from roost sites (Krapu et al. 2014). We determined identity of crops cultivated in the region with National Agricultural Statistics
Service CropScape data for the growing years associated with our roost data (2002-2006; United States Department of Agriculture National Agriculture Statistics Service Cropland Data Layer 2002-2006; https://nassgeodata. gmu.edu/CropScape/, accessed 10 Jun 2014).

We calculated three additional covariates that corresponded to temporally varying conditions during spring. To characterize water conditions on the river, we included daily mean discharge $\left(\mathrm{m}^{3} / \mathrm{s}\right)$ estimated from a United States Geological Survey gaging station near Grand Island, Nebraska to describe water conditions over the entire reach (site no. 06770500; http://waterdata.usgs.gov, accessed 09 Jun 2014). We also included 2 covariates to characterize nightly weather conditions during spring migration. From hourly weather data reported at Central Nebraska Regional Airport near Grand Island (National Climactic Data Center, http://www.ncdc.noaa.gov, accessed 09 Jun 2014), we calculated minimum temperature $\left({ }^{\circ} \mathrm{C}\right)$ and median wind speed $(\mathrm{km} / \mathrm{hr})$ each evening from observations collected between 1900 hours and 2300 hours.

\section{Model Development}

We included channel width and bank vegetation height in models representing perceived security along segments of river. We included these in models as independent and as interacting factors because we suspected that the influence of bank vegetation height might be more pronounced at narrower compared to wider channels. To investigate weather-mediated roost selection, we developed a model that included an interaction between ambient temperature and channel width, and an interaction between average wind speed and bank vegetation height to test our predictions that cranes would favor sheltered sites during cold and windy conditions.

Areas within the river channel suitable for crane roosts have been identified based partially on water depth (Folk and Tacha 1990, Norling et al. 1992). Kinzel et al. (2009) predicted area of suitable depth for crane roosts as a nonlinear relationship of river stage, where moderate flows corresponded with the greatest roost area. In addition, Farmer et al. (2005) reported varying relationships between river discharge and available habitat for roosting whooping cranes (Grus americana), depending partially on channel width along the Platte River. Therefore, we developed a model that included quadratic river discharge as it interacts with channel width as surrogate for water depth within each segment.

Presence of disturbance features related to human activity, including roads, river bridges, and dwellings influenced use of river roost sites, and cranes selected sites farther from such disturbances (Krapu et al. 1984, Norling et al. 1992, Parrish et al. 2001). We included a model that investigated how disturbances from various anthropogenic sources might modify roost site selection. We natural $\log$ transformed distance to disturbance because effects of disturbance often decline at greater distances (Fedy and Martin 2011, Dinkins et al. 2014). In addition, we included interactions of channel width and bank vegetation to determine if anthropogenic 
disturbance features could influence relations with these covariates.

Land cover surrounding roost sites, especially foraging sites, influences roost site selection (Morrison and Caccamise 1985, Zharikov and Milton 2009). Cranes use cornfields extensively in Nebraska as foraging sites containing highenergy content foods, and their main food is waste grain (Krapu et al. 1984, 2014, Iverson et al. 1987). We included a model that had the additive effect of proportion of cornfields surrounding roost sites to determine if varying amounts of this key foraging resource influenced roost selection. We also included interactions with channel width and bank vegetation height to determine if different channel characteristics influenced selection sites with varying amounts of foraging habitats in proximity to the river.

\section{Statistical Analyses}

We used conditional logistic regression in a discrete choice framework to explore patterns of selection for various parameters characterizing river sections (Compton et al. 2002, McDonald et al. 2006). This method facilitated comparison of used sites with a set of available random sites nearby that the bird could have selected. We inspected correlations among spatial and temporal covariates by calculating correlation coefficients. If relationships between covariates were strong $(|r|>0.5)$, we restricted use of both variables in the same model. We used Akaike's Information Criterion (AIC) values to rank models and considered those with $\Delta \mathrm{AIC}<2$ as competitive (Burnham and Anderson 2003). For models not considered competitive, we also identified potentially informative parameters if nested models without parameters had AIC value $>2$ units and if confidence intervals of parameter estimates did not include 0 . We performed analyses in SAS using the LOGISTIC procedure (SAS Institute). We paired each roost site with 20 available locations using the strata option. We interpreted log odds ratios for regression coefficients because values $<0$ reflect a negative relationship, whereas values $>0$ reflect a positive relationship with the covariate (Godvik et al. 2009, Blix et al. 2014).

We used $k$-fold cross validation procedures to assess the predictive ability of our highest-ranked model. We used 5 folds and derived a rank correlation between the bin rank and frequency of test locations across 10 equal-sized resource selection function bins (Boyce et al. 2002).

\section{RESULTS}

We identified 6,310 roost sites selected by 313 sandhill cranes over 5 spring migration seasons to quantify roost-site selection at the central Platte River. We located 1,230 roosts during 2003, 1,329 during 2004, 1,536 during 2005, 1,415 during 2006, and 800 during 2007. Across years we identified roosts between 20 February and 14 April. Across all 400-m river segments, we found a wide range of measurements for channel width, maximum bank vegetation height, distance to disturbance features, and proportion of land adjacent to roost sites with harvested cornfields (Table 1). Spring weather conditions varied greatly among nights that cranes roosted (Table 1).
Of the 6 models designed to explain variation in night roost selection, a single model outperformed others (secondranked model $\Delta \mathrm{AIC}=905.3$; Table 2). This model included effects of channel width, bank vegetation height, lntransformed distance to disturbance, and second-order interactions among main effects. Results of the $k$-fold cross-validation analysis revealed an average rank correlation of 0.971 between 10 ranked bins and validation locations ( $\rho=0.956-1.0$ ), which indicated the model performed well at predicting roost site use within the study area. The bestsupported model revealed that cranes selected roost sites more favorably as channel width increased and as bank vegetation height decreased (Table 3; Fig. 2). An interaction between these effects suggested selection for short bank vegetation height was slightly less intense at wider channel widths (Fig. 2A) and that selection for wide channel widths was more intense when bank vegetation was taller (Fig. 2B). Nonetheless, selection for wide over narrow channels was relatively similar over the entire range of bank vegetation heights available along the central Platte River (Fig. 2).

Selection for roost sites generally increased at greater distances from disturbance features. This relationship was more pronounced when disturbances were close $(<\sim 300 \mathrm{~m})$ and weakened at greater distances (Fig. 3A and B). The effect size for distance to disturbance feature was contingent on channel width and bank vegetation height at a particular river reach. Roost sites with relatively close disturbances $(51 \mathrm{~m})$ and narrow channels were selected against more strongly than narrow channels with more distant disturbances (755 m; Fig. 3C). Effect size decreased with increasing channel width, and 95\% confidence intervals overlapped at disturbance distances approximately $700 \mathrm{~m}$ for narrow $(29 \mathrm{~m})$ and wide $(279 \mathrm{~m})$ channels (Fig. 3A). Disturbances close to roost sites negatively influenced selection more prominently at sites with tall $(12.1 \mathrm{~m})$ compared with short $(1.1 \mathrm{~m})$ bank vegetation (Fig. 3B). For sites at greater distances from disturbance features $(755 \mathrm{~m})$, bank vegetation height had only a modest effect on selection, whereas for sites with closer disturbance features $(51 \mathrm{~m})$, bank vegetation height had a larger effect on site selection (Fig. 3D).

Although our top model outperformed others by a considerable margin, models ranked second and third included informative parameters. The second-ranked model represented available foraging adjacent to roost sites and performed better than a nested model without these covariates (AIC difference $=108.6$; Table 2). Results of this model suggested that the proportion of area in corn agriculture adjacent to river roost sites influenced selection of sites with narrow channels whereas, at modest widths of approximately $>100 \mathrm{~m}$, adjacent cornfields did not influence selection (Fig. 4A). An interaction between bank vegetation height and adjacent cornfields suggested that cranes selected roost sites more strongly as the proportion of adjacent corn increased only when bank vegetation was relatively short $(\leq 8 \mathrm{~m})$ at a median channel width (Fig. 4B). Thus, the influence of adjacent cornfields on roost selection was only apparent for sites with relatively short bank vegetation or narrow channel widths. 
Table 1. Univariate summaries of covariates used to parameterize models of roost site selection of spring-migrating sandhill cranes along the central Platte River in Nebraska, USA, during 2003-2006.

\begin{tabular}{|c|c|c|c|c|c|c|}
\hline Covariate & $\overline{\boldsymbol{x}}$ & SD & Median & $5 \%$ & $95 \%$ & Min.-Max. \\
\hline Channel width (m) & 110 & 87 & 72 & 29 & 279 & $18-460$ \\
\hline Bank vegetation height $(\mathrm{m})$ & 6.8 & 3.2 & 7.0 & 1.1 & 12.4 & $0.1-16.5$ \\
\hline Distance to disturbance (m) & 354 & 229 & 326 & 51 & 755 & $1-1,161$ \\
\hline Temperature $\left({ }^{\circ} \mathrm{C}\right)$ & 11.3 & 7.5 & 11.7 & -0.6 & 23.3 & -15.6 to 30.6 \\
\hline Wind speed $(\mathrm{m} / \mathrm{s})$ & 6.7 & 2.8 & 6.5 & 2.6 & 11.3 & $0.8-18.0$ \\
\hline River discharge $\left(\mathrm{m}^{3} / \mathrm{s}\right)$ & 20.9 & 9.3 & 17.3 & 11.5 & 37.4 & $8.3-100.3$ \\
\hline Proportion of landscape in corn agriculture & 0.25 & 0.09 & 0.26 & 0.09 & 0.37 & $0.02-0.50$ \\
\hline
\end{tabular}

The third-ranked model included ambient conditions and performed better than a nested model without these effects (AIC difference $=24.6$ ). In this model, the interaction between ambient temperature and channel width had a confidence interval that did not overlap 0 (Table S1, available online in Supporting Information). The effect of temperature was in the opposite direction of expectation, where cranes selected for wider channels more strongly on colder compared to warmer nights. Our model that included river flow as it interacted with channel width did not outperform models without these covariates (AIC difference $=0.4$ ).

\section{DISCUSSION}

Studies of resource selection provide valuable insight into habitat characteristics that animals use to meet basic needs for survival and reproduction. We confirmed key resource features that sandhill cranes selected at river channels along the Platte River, a major spring-staging area. Managers can use information on roost-site selection to increase probability of crane use at existing roost sites and to develop new areas for potential use if existing sites become limited. Selection for resources can vary in space and time because of numerous ecological and environmental factors (McLoughlin et al. 2010); therefore, incorporating such variation makes resource selection models more robust. When we integrated spatial variation in crane use due to human disturbance factors, our models were greatly improved and provided contexts in which potential disturbances interacted with physical habitat features. Moreover, understanding factors influencing spatial and temporal variation in use of roost sites provided for a greater understanding of habitat cranes require to meet needs within varying environmental and ecological contexts.
Physical features that have defined sandhill crane roost sites were supported by our results. Roosting cranes showed stronger selection for channels that were wider and with shorter bank vegetation. Previous studies reported that channel width and bank vegetation height influenced roost selection by sandhill cranes along the Platte River (Krapu et al. 1984, Folk and Tacha 1990, Norling et al. 1992, Parrish et al. 2001, Davis 2003). Our data indicated these factors interacted with one another such that the magnitude of effect for bank vegetation height attenuated with increased channel width. Krapu et al. (1984) reported similar findings, where vegetation height influenced roost use in channels of moderate widths $(50-150 \mathrm{~m})$ but not for wider and more frequently used channels $>150 \mathrm{~m}$ wide. This preference for open roost sites is not unique; bar-tailed godwits (Limosa lapponica) and eastern curlews (Numenius madagascariensis) selected roost sites based on size of roost and greater field of view (Zharikov and Milton 2009). The prevailing explanation for preference of wide channels with short bank vegetation has been linked to anti-predator behavior (i.e., roost sites are selected that provide cranes with a relatively unobstructed view of their surroundings, presumably allowing them to detect, and evade predators more easily; Krapu et al. 1984).

Human disturbance as indexed by distance to roads, bridges, and other human development also influenced roost site selection. In general, sandhill cranes showed stronger selection for sites as disturbance distance increased. The effect of disturbance distance was more pronounced for nearby disturbances up to approximately $200 \mathrm{~m}$, and the magnitude of effect decreased at greater distances. Incorporating disturbance into resource selection models has

Table 2. Model selection for resource selection functions of spring-migrating sandhill cranes roosting along the central Platte River in Nebraska, USA, during 2003-2006.

\begin{tabular}{lrr}
\hline Model structure $^{\mathbf{a}}$ & $\boldsymbol{K}^{\mathbf{b}}$ & $\boldsymbol{\Delta A I C}^{\mathbf{c}}$ \\
\hline $\mathrm{CW}+\mathrm{VH}+\mathrm{DD}+\mathrm{CW} \times \mathrm{VH}+\mathrm{CW} \times \mathrm{DD}+\mathrm{VH} \times \mathrm{DD}$ & 6 & 0 \\
$\mathrm{CW}+\mathrm{VH}+\mathrm{CN}+\mathrm{CW} \times \mathrm{VH}+\mathrm{CW} \times \mathrm{CN}+\mathrm{VH} \times \mathrm{CN}$ & 6 & 905.3 \\
$\mathrm{CW}+\mathrm{VH}+\mathrm{CW} \times \mathrm{VH}+\mathrm{CW} \times \mathrm{TP}+\mathrm{VH} \times \mathrm{WS}$ & 5 & 989.3 \\
$\mathrm{CW}+\mathrm{VH}+\mathrm{CW} \times \mathrm{VH}+\mathrm{CW} \times \mathrm{FL}+\mathrm{CW} \times \mathrm{FL}$ & 5 & $1,013.5$ \\
$\mathrm{CW}+\mathrm{VH}+\mathrm{CW} \times \mathrm{VH}$ & 3 & $1,013.9$ \\
$\mathrm{CW}+\mathrm{VH}$ & 2 & $1,103.1$ \\
\hline
\end{tabular}

${ }^{a} \mathrm{CW}$, channel width; $\mathrm{VH}$, bank vegetation height; $\mathrm{DD}, \mathrm{ln}$-transformed distance to nearest disturbance feature; CN, proportion of area in corn agriculture; TP, nightly minimum temperature; WS, average nightly wind speed; FL, average daily stream discharge.

${ }^{\mathrm{b}}$ Number of estimated parameters.

${ }^{\mathrm{c}}$ Difference between the minimum Akaike's Information Criterion (AIC) value and the AIC of the current model. The AIC of the top model = 30,501.0. 
Table 3. Parameter estimates (log odds ratio), standard errors, and $95 \%$ confidence intervals from the highest-ranked model estimating resource selection functions of spring-migrating sandhill cranes roosting along the central Platte River in Nebraska, USA, during 2003-2006.

\begin{tabular}{lrlrr}
\hline Variable $^{\mathbf{a}}$ & Estimate & \multicolumn{1}{c}{ SE } & Lower CI & Upper CI \\
\hline $\mathrm{CW}$ & 0.0236 & 0.0014 & 0.0209 & 0.0263 \\
$\mathrm{VH}$ & -0.9271 & 0.0552 & -1.0353 & -0.8189 \\
$\mathrm{DD}$ & 0.3597 & 0.0720 & 0.2186 & 0.5008 \\
$\mathrm{CW} \times \mathrm{VH}$ & 0.0002 & $4.3 \times 10^{-5}$ & 0.0001 & 0.0002 \\
$\mathrm{CW} \times \mathrm{DD}$ & -0.0027 & 0.0002 & -0.0032 & -0.0023 \\
$\mathrm{VH} \times \mathrm{DD}$ & 0.1336 & 0.0089 & 0.1162 & 0.1510 \\
\hline
\end{tabular}

a $\mathrm{CW}$, channel width (m); VH, bank vegetation height (m); DD, ln-transformed distance to nearest disturbance feature (m).

improved performance and predictive ability in a wide range of situations (Pitman et al. 2005, Doherty et al. 2008, Sawyer et al. 2009, Harju et al. 2011, Meager et al. 2012). Past studies of roosting cranes also support that distance to
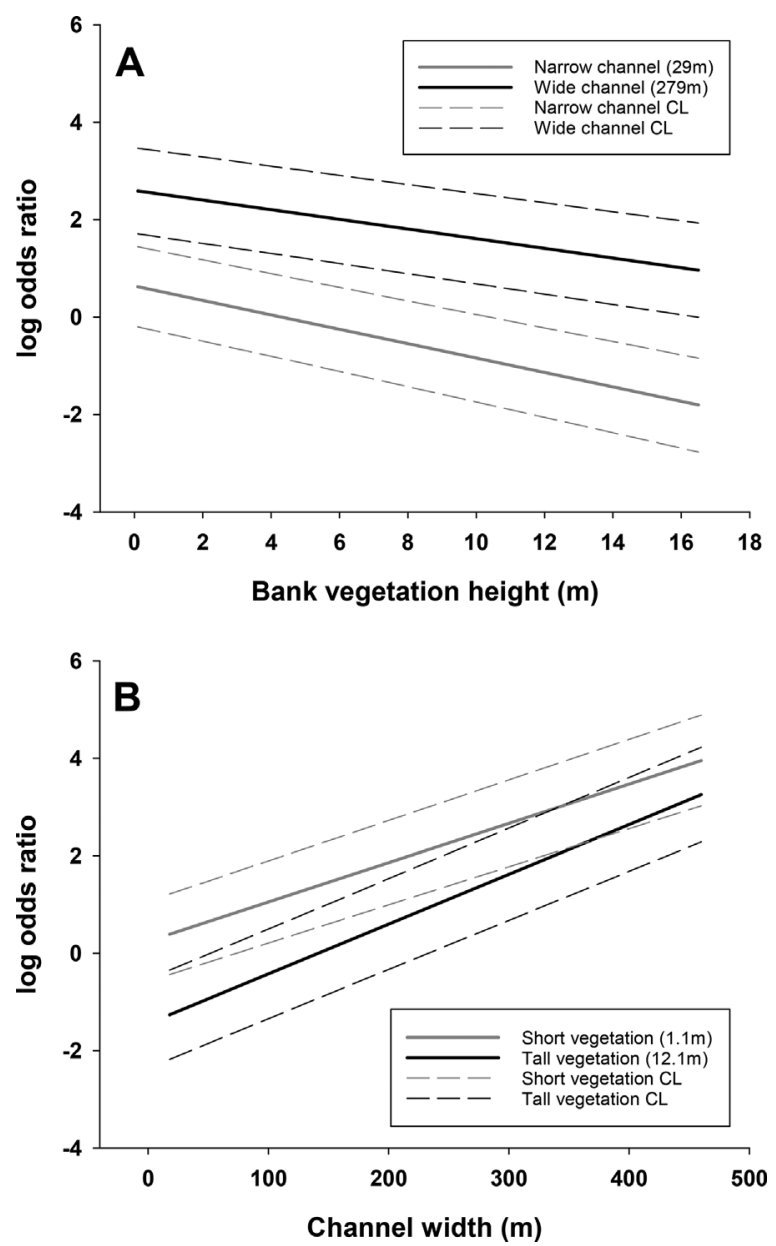

Figure 2. Estimates of $\log$ odds ratio and $95 \%$ confidence limits describing roost-site selection of spring-migrating sandhill cranes along the central Platte River in Nebraska, USA, 2003-2006. We provided estimates at narrow $(29 \mathrm{~m})$ and wide $(279 \mathrm{~m})$ channels along a gradient of bank vegetation heights $(\mathrm{A})$ and at channels with short $(1.1 \mathrm{~m})$ and tall $(12.1 \mathrm{~m})$ bank vegetation along a gradient of channel widths (B). We indexed estimates relative to the $\log$ odds ratio based on median values for all covariates, such that values $>0$ represent selection for sites relative to median values and values $<0$ represent relative avoidance. features such as bridges and roads influenced use and selection of roost sites (Krapu et al. 1984, Norling et al. 1992, Parrish et al. 2001). The prevalence of human activity across numerous ecosystems and landscapes provides impetus for researchers to incorporate disturbance factors into habitat selection models.

Responses to human disturbance are not constant and can vary among species, individual, and type of disturbance (Schummer and Eddleman 2003, Beale and Monaghan 2004, Blumstein et al. 2005). In our study, the influence of disturbance distance on sandhill cranes varied depending on physical characteristics of roost sites. The avoidance of roost sites with nearby disturbance features was most pronounced at river sites with channel characteristics less likely to be selected by cranes (i.e., more narrow channels with taller bank vegetation). Thus, at river reaches where physical conditions were less optimal for roosting cranes, disturbance features had a pronounced negative influence on probability of site selection. This synergistic relationship suggests nearby disturbance features accentuated reductions in roost site attractiveness based solely on degraded physical characteristics, accelerating loss of less preferred roost sites. Alternatively, sites with more preferable physical characteristics were somewhat resilient to nearby disturbance features, although disturbances continued to negatively affect relative probability of use compared to sites without nearby disturbances. One potential explanation for these results is that cranes may perceive human disturbances similarly to predators (Frid and Dill 2002). If cranes perceive wide and open roost sites as relatively safe from predators, they may be less affected by presence of disturbance features than at sites they perceive having a greater predation risk.

Avoidance of human disturbance features that result in reduced use of areas otherwise suitable for wildlife has been interpreted as indirect habitat loss (Sawyer et al. 2009, Polfus et al. 2011). Generally, presence of disturbance features within approximately $200 \mathrm{~m}$ reduced the relative probability of crane use at roost sites, suggesting that cranes avoided certain areas primarily because of proximate disturbance features. Interactions between disturbance distance and physical channel characteristics provide evidence that indirect habitat loss may be partially abated because effects of disturbance distance were reduced at sites that were most highly selected by cranes.

Sandhill cranes and other migratory birds require resources beyond suitable and safe roost sites at migration stopover sites (Stafford et al. 2014). In particular, sandhill cranes need access to high energy foods, which they obtain primarily from waste corn, and protein and other resources acquired in grasslands and wetlands (Reinecke and Krapu 1986, Krapu et al. 2014). Roost selection of various shorebirds has been related to proximity of resource-rich foraging areas (Dias et al. 2006, Rogers et al. 2006, Zharikov and Milton 2009). Proximity of roost and foraging sites can influence daily energetics. Kahlert (2006) reported that variation in daily foraging flight distance influenced body condition and daily mass loss in greylag geese (Anser anser). A lack of nearby roost 

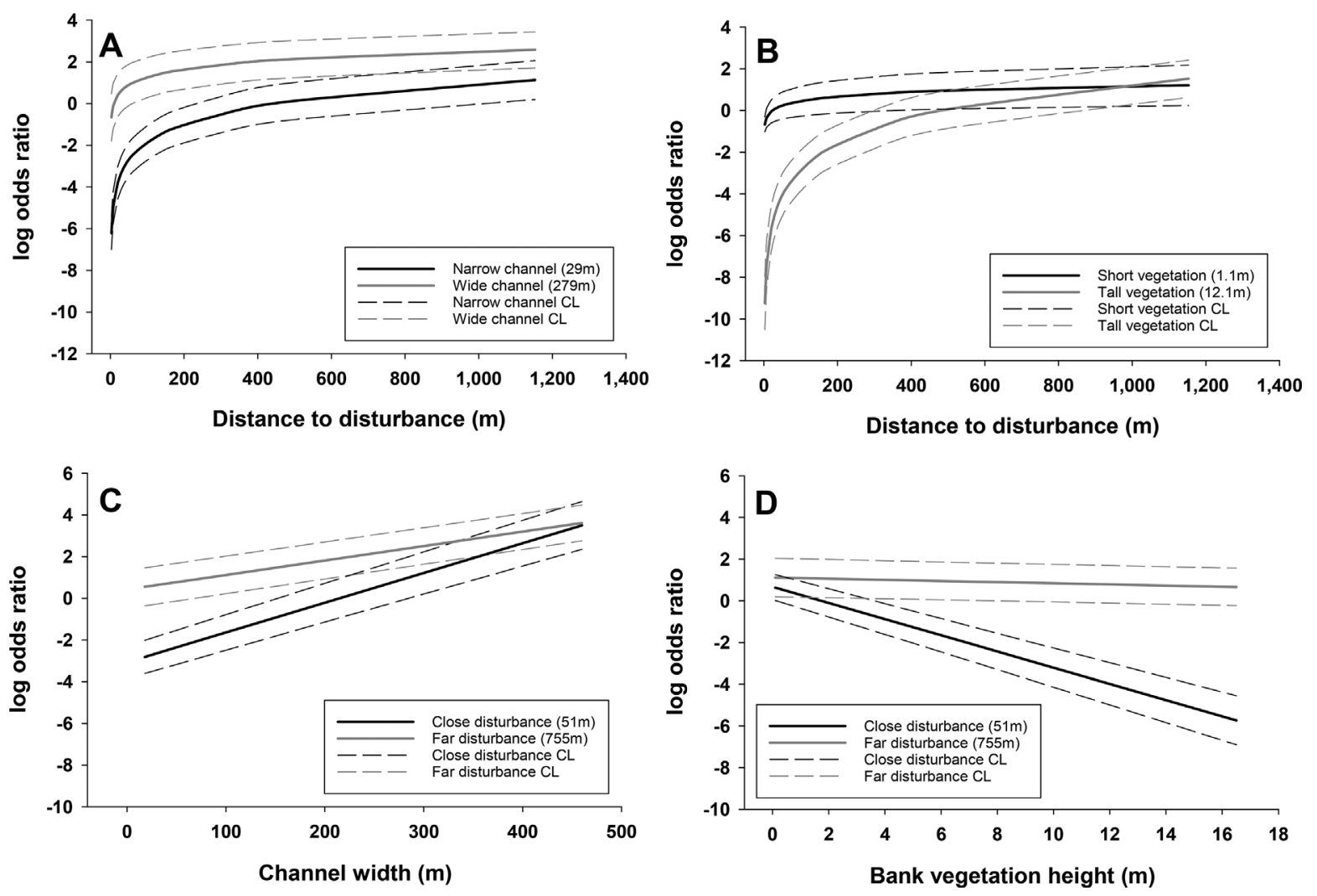

Figure 3. Estimates of log odds ratio and $95 \%$ confidence limits describing roost-site selection of spring-migrating sandhill cranes along the central Platte River in Nebraska, USA, 2003-2006. We provided estimates at narrow $(29 \mathrm{~m})$ and wide $(279 \mathrm{~m})$ channels along a gradient of distance to human disturbance features $(\mathrm{A})$, at channels with short $(1.1 \mathrm{~m})$ and tall $(12.1 \mathrm{~m})$ bank vegetation along a gradient of distance to human disturbance features $(\mathrm{B})$, relatively close $(51 \mathrm{~m})$ and more distant $(755 \mathrm{~m})$ disturbance features along a gradient of channel width $(\mathrm{C})$, and relatively close $(51 \mathrm{~m})$ and more distant $(755 \mathrm{~m})$ disturbance features along a gradient of bank vegetation height (D). We indexed estimates relative to the log odds ratio based on median values for all covariates, such that values $>0$ represent selection for sites relative to median values and values $<0$ represent relative avoidance.

sites may explain why certain foraging resources are not used as widely by migrating birds, including sandhill cranes (Dias et al. 2006, Pearse et al. 2010, Anteau et al. 2011, Chudzińska et al. 2015). In support of this notion, our data indicate that the amount of cornfields surrounding sandhill crane roost sites positively influenced relative probability of use but only for narrow channels and those with shorter bank vegetation. Thus, physical characteristics of roost sites were more influential in determining relative probability of roost use by cranes, whereas landscape composition characteristics were of secondary importance and only for channels with certain physical characteristics.

Some of our hypotheses that included temporally varying selection did not explain roost selection well. We predicted that cranes might select more narrow channels during colder conditions and channels with taller bank vegetation during evenings of increased wind speeds to find roosts that were more energetically favorable. Sandhill cranes are relatively large birds ( 3.4-4.3 kg; Krapu et al. 2014) and may be able to thermoregulate without expending considerable energy reserves under the range of conditions they can experience during late winter-early spring in Nebraska. Water depth has been identified as a characteristic that influences use of river roost sites for cranes (Folk and Tacha 1990, Norling et al. 1992). We used the interaction of river flow and channel width as a surrogate for water depth, yet including these interacting effects did not improve model performance. We suspect 2 factors that may have led to this result. First, we used average daily river discharge, which may not reflect exact conditions during the evening and night as birds are selecting, and using roost sites. Second, our surrogate for water depth may have been over simplified. Kinzel et al. (2009) reported that specific channel morphology, which can change rapidly, and discharge were required when attempting to estimate available roost area at river reaches. We lacked this detailed information for the entire study area.

\section{MANAGEMENT IMPLICATIONS}

Increases in relative crane use will be realized when increasing channel width within the range of widths we observed. Reducing height of bank vegetation also should increase relative crane use, but gains will be more noticeable at channel widths approximately $<200 \mathrm{~m}$. At sites of moderate channel width or vegetation height, removing existing disturbances, where feasible, may realize greater increase in roost site use rather than working directly on the physical characteristics, which may be more expensive to manipulate. When disturbance features are at greater distances $(>300-400 \mathrm{~m})$, manipulation of channel width and bank vegetation height will have greater influence on crane use. Generally, presence of disturbance features within $200 \mathrm{~m}$ of roost sites reduced the probability of crane use 

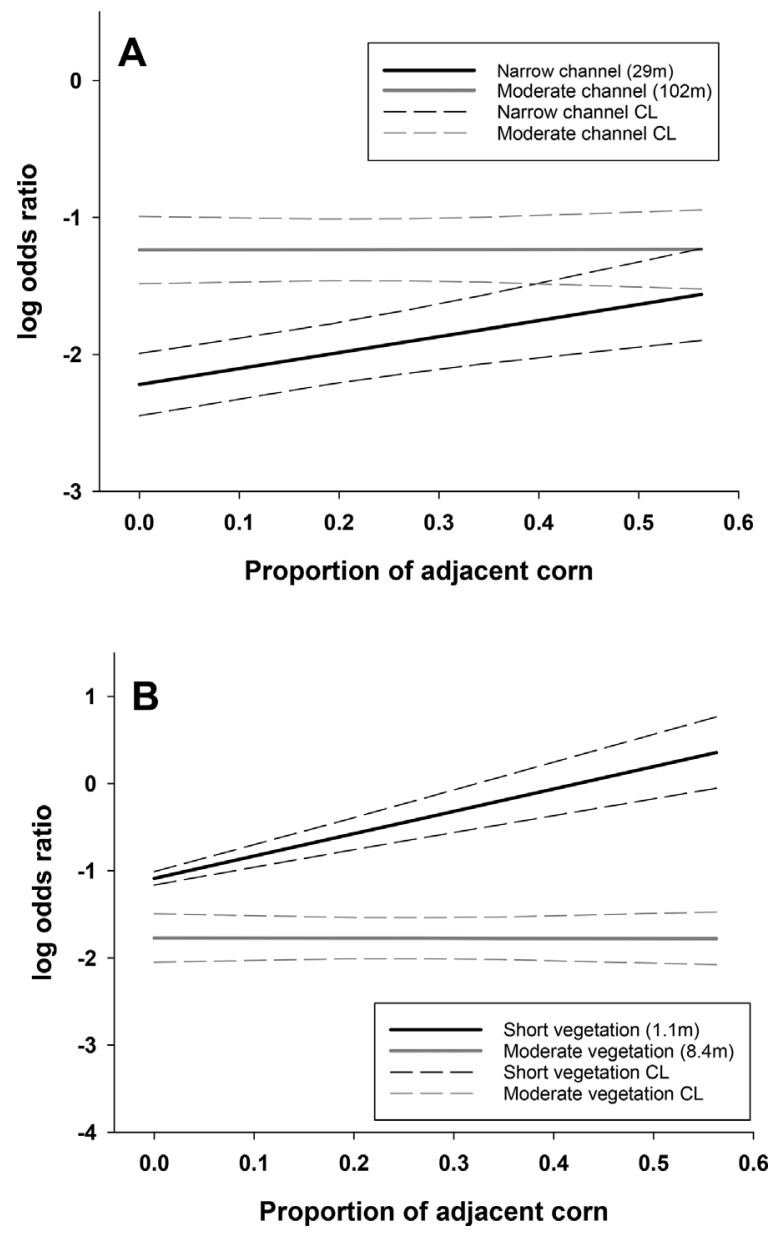

Figure 4. Estimates of $\log$ odds ratio and $95 \%$ confidence limits describing roost-site selection of spring-migrating sandhill cranes along the central Platte River in Nebraska, USA, 2003-2006. We provided estimates along a gradient of proportion of 1,256 ha surrounding roost sites planted to corn agriculture at narrow $(29 \mathrm{~m})$ and moderate $(102 \mathrm{~m})$ channels $(A)$, and at channels with short $(1.1 \mathrm{~m})$ and moderate $(8.4 \mathrm{~m})$ bank vegetation height (B). We indexed estimates relative to the log odds ratio based on median values for all covariates, such that values $>0$ represent selection for sites relative to median values and values $<0$ represent relative avoidance.

substantially, providing managers insight concerning potential set-back distances from any proposed construction of features that may be perceived as disturbance by roosting cranes. The amount of cornfields surrounding certain nocturnal roost sites positively influenced roost site use. Cornfields remain widely distributed in the central Platte River Valley, yet potential decreases in corn agriculture at certain locations might influence use of roost sites, especially at channel widths $<100 \mathrm{~m}$, which represented $60 \%$ of available roost sites. Maintaining high energy foods near roost sites along the entire river corridor may support a more even distribution of cranes, reducing risks that high densities of animals can pose such as disease transmission.

\section{ACKNOWLEDGMENTS}

Any use of trade, firm, or product names is for descriptive purposes only and does not imply endorsement by the U.S. Government. We thank D. Fronczak, A. Olson, A. Stonsifer, J. Drahota, W.Jones, T. Buhl, F. Sargeant,
J. Feist, L. Wood, S. Hawks, D. Grandmaison, M. Westbrock, K. Seginak, B. Hanson, C. Mettenbrink, R. Knopik, C. Graue, V. Carter, B. Geaumont, J. McCabe, D. Smith, L. Potter, J. Thibault, B. Toay, M. Stoley, M. Heiser, and M. Pieron for field assistance. W. E. Newton processed Lidar data. F. Boutin provided geographic information system (GIS) support. A. J. Caven, D. A. Aborn, and anonymous reviewers provided comments on earlier versions of this manuscript. We thank the Region 6 of the U.S. Fish and Wildlife Service, and U.S. Geological Survey-Platte River Priority Ecosystems Study, Central Flyway Council, and the Webless Migratory Game Bird Research Fund for funding and in-kind assistance.

\section{LITERATURE CITED}

Anteau, M. J., M. H. Sherfy, and A. A. Bishop. 2011. Location and agricultural practices influence spring use of harvested cornfields by cranes and geese in Nebraska. Journal of Wildlife Management 75:1004-1011.

Arthur, S. M., B. F. Manly, L. L. McDonald, and G. W. Garner. 1996. Assessing habitat selection when availability changes. Ecology 77:215-227.

Beale, C. M., and P. Monaghan. 2004. Behavioural responses to human disturbance: a matter of choice? Animal Behaviour 68:1065-1069.

Blix, A. W., A. Mysterud, L. E. Loe, and G. Austrheim. 2014. Temporal scales of density-dependent habitat selection in a large grazing herbivore. Oikos 123:933-942.

Blumstein, D. T., E. Fernández-Juricic, P. A. Zollner, and S. C. Garity. 2005. Inter-specific variation in avian responses to human disturbance. Journal of Applied Ecology 42:943-953.

Bock, A., B. Naef-Daenzer, H. Keil, F. Korner-Nievergelt, M. Perrig, and M. U. Gruebler. 2013. Roost site selection by little owls Athene noctua in relation to environmental conditions and life-history stages. Ibis 155:847-856.

Boyce, M. S., P. R. Vernier, S. E. Nielsen, and F. K. Schmiegelow. 2002. Evaluating resource selection functions. Ecological Modelling 157:281-300.

Brei, J., A. A. Bishop, and R. B. J. Venture. 2008. Platte River vegetation mapping project 2005 land cover methods summary. Great Plains GIS Partnership, Grand Island, Nebraska, USA.

Burnham, K. P., and D. R. Anderson. 2003. Model selection and multimodel inference: a practical information-theoretic approach. Springer-Verlag, New York, New York, USA.

Buttemer, W. A. 1985. Energy relations of winter roost-site utilization by American goldfinches (Carduelis tristis). Oecologia 68:126-132.

Chudzińska, M. E., F. M. van Beest, J. Madsen, and J. Nabe-Nielsen. 2015. Using habitat selection theories to predict the spatiotemporal distribution of migratory birds during stopover-a case study of pink-footed geese Anser brachyrhynchus. Oikos 124:851-860.

Compton, B. W., J. M. Rhymer, and M. McCollough. 2002. Habitat selection by wood turtles (Clemmys insculpta): an application of paired logistic regression. Ecology 83:833-843.

Cox, Jr. R. R., and A. D. Afton. 1996. Evening flights of female northern pintails from a major roost site. Condor 98:810-819.

Davis, C. A. 2003. Habitat use and migration patterns of sandhill cranes along the Platte River, 1998-2001. Great Plains Research 13:199-216.

Dias, M. P., J. P. Granadeiro, M. Lecoq, C. D. Santos, and J. M. Palmeirim. 2006. Distance to high-tide roosts constrains the use of foraging areas by dunlins: implications for the management of estuarine wetlands. Biological Conservation 131:446-452.

Dinkins, J. B., M. R. Conover, C. P. Kirol, J. L. Beck, and S. N. Frey. 2014. Greater sage-grouse (Centrocercus urophasianus) select habitat based on avian predators, landscape composition, and anthropogenic features. Condor 116:629-642.

Doherty, K. E., D. E. Naugle, B. L. Walker, and J. M. Graham. 2008. Greater sage-grouse winter habitat selection and energy development. Journal of Wildlife Management 72:187-195.

Faanes, C. A., and M. J. LeValley. 1993. Is the distribution of sandhill cranes on the Platte River changing? Great Plains Research 3:297-304.

Farmer, A. H., B. S. Cade, J. W. Terrell, J. H. Henriksen, and J. T. Runge. 2005. Evaluation of models and data for assessing whooping 
crane habitat in the central Platte River, Nebraska. U.S. Geological Survey Scientific Investigations Report 2005-5123, Reston, Virginia, USA.

Fedy, B., and K. Martin. 2011. The influence of fine-scale habitat features on regional variation in population performance of alpine white-tailed ptarmigan. Condor 113:306-315.

Folk, M. J., and T. C. Tacha. 1990. Sandhill crane roost site characteristics in the North Platte River Valley. Journal of Wildlife Management 54:480-486.

Frid, A., and L. M. Dill. 2002. Human-caused disturbance stimuli as a form of predation risk. Conservation Ecology 6:art.11.

Gaunt, A. S., L. W. Oring, and O. Council. 1999. Guidelines to the use of wild birds in research. Ornithological Council, Washington, D.C., USA.

Godvik, I. M. R., L. E. Loe, J. O. Vik, V. Veiberg, R. Langvatn, and A. Mysterud. 2009. Temporal scales, trade-offs, and functional responses in red deer habitat selection. Ecology 90:699-710.

Harju, S., M. Dzialak, R. Osborn, L. Hayden-Wing, and J. Winstead. 2011. Conservation planning using resource selection models: altered selection in the presence of human activity changes spatial prediction of resource use. Animal Conservation 14:502-511.

Haugerud, R. A., and D. Harding. 2001. Some algorithms for virtual deforestation (VDF) of LIDAR topographic survey data. International Archives of Photogrammetry Remote Sensing and Spatial Information Sciences 34:211-218.

Hiller, T. L., and F. S. Guthery. 2005. Microclimate versus predation risk in roost and covert selection by bobwhites. Journal of Wildlife Management 69:140-149.

Iverson, G. C., P. A. Vohs, and T. C. Tacha. 1987. Habitat use by midcontinent sandhill cranes during spring migration. Journal of Wildlife Management 51:448-458.

Kahlert, J. 2006. Effects of feeding patterns on body mass loss in moulting greylag geese Anser anser: capsule body mass loss was mainly affected by daily travel distance between roost site and feeding patches. Bird Study 53:20-31.

Kessler, A. C., J. W. Merchant, S. D. Shultz, and C. R. Allen. 2013. Costeffectiveness analysis of sandhill crane habitat management. Journal of Wildlife Management 77:1301-1310.

Kinzel, P., J. Nelson, and A. Heckman. 2009. Response of sandhill crane (Grus canadensis) riverine roosting habitat to changes in stage and sandbar morphology. River Research and Applications 25:135-152.

Krapu, G. L., D. A. Brandt, P. J. Kinzel, and A. T. Pearse. 2014. Spring migration ecology in the mid-continent population of sandhill cranes with an emphasis on the central Platte River Valley, Nebraska. Wildlife Monographs 189:1-44.

Krapu, G. L., D. E. Facey, E. K. Fritzell, and D. H. Johnson. 1984. Habitat use by migrant sandhill cranes in Nebraska. Journal of Wildlife Management 48:407-417.

Krapu, G. L., G. C. Iverson, K. J. Reinecke, and C. M. Boise. 1985. Fat deposition and usage by arctic-nesting sandhill cranes during spring. Auk 102:362-368.

Krapu, G. L., K. J. Reinecke, and C. R. Frith. 1982. Sandhill cranes and the Platte River. Transactions of the North American Wildlife and Natural Resources Conference 47:542-552.

Lambertucci, S. A., and A. Ruggiero. 2013. Cliffs used as communal roosts by Andean condors protect the birds from weather and predators. PLoS ONE 8:e67304.

Lewis, J. C. 1976. Roost habitat and roosting behavior of sandhill cranes in the southern Central Flyway. Pages 93-104 in J. C. Lewis, editor. Proceedings of the International Crane Workshop. International Crane Foundation, Stillwater, Oklahoma, USA.

Manly, B., L. McDonald, D. Thomas, T. L. McDonald, and W. P. Erickson. 2002. Resource selection by animals: statistical design and analysis for field studies. Springer, Dordrecht, Netherlands.

McDonald, T. L., B. F. Manly, R. M. Nielson, and L. V. Diller. 2006. Discrete-choice modeling in wildlife studies exemplified by northern spotted owl nighttime habitat selection. Journal of Wildlife Management 70:375-383.

McLoughlin, P. D., D. W. Morris, D. Fortin, E. Vander Wal, and A. L. Contasti. 2010. Considering ecological dynamics in resource selection functions. Journal of Animal Ecology 79:4-12.
Meager, J. J., T. A. Schlacher, and T. Nielsen. 2012. Humans alter habitat selection of birds on ocean-exposed sandy beaches. Diversity and Distributions 18:294-306.

Morris, D. W. 2003. Toward an ecological synthesis: a case for habitat selection. Oecologia 136:1-13.

Morrison, D. W., and D. F. Caccamise. 1985. Ephemeral roosts and stable patches? A radiotelemetry study of communally roosting starlings. Auk 102:793-804.

Norling, B. S., S. H. Anderson, and W. A. Hubert. 1992. Roost sites used by sandhill crane staging along the Platte River, Nebraska. Great Basin Naturalist 52:253-261.

Parrish, T. L., W. A. Hubert, S. H. Anderson, M. Pucherelli, and W. Mangus. 2001. Distributions of roosting sandhill cranes as identified by aerial thermography. Prairie Naturalist 33:93-99.

Pearse, A. T., G. L. Krapu, D. A. Brandt, and P. J. Kinzel. 2010. Changes in agriculture and abundance of snow geese affect carrying capacity of sandhill cranes in Nebraska. Journal of Wildlife Management 74: 479-488.

Peters, K. A., and D. L. Otis. 2007. Shorebird roost-site selection at two temporal scales: is human disturbance a factor? Journal of Applied Ecology 44:196-209.

Pfister, C., B. A. Harrington, and M. Lavine. 1992. The impact of human disturbance on shorebirds at a migration staging area. Biological Conservation 60:115-126.

Pitman, J. C., C. A. Hagen, R. J. Robel, T. M. Loughin, and R. D. Applegate. 2005. Location and success of lesser prairie-chicken nests in relation to vegetation and human disturbance. Journal of Wildlife Management 69:1259-1269.

Polfus, J., M. Hebblewhite, and K. Heinemeyer. 2011. Identifying indirect habitat loss and avoidance of human infrastructure by northern mountain woodland caribou. Biological Conservation 144:2637-2646.

Reinecke, K. J., and G. L. Krapu. 1986. Feeding ecology of sandhill cranes during spring migration in Nebraska. Journal of Wildlife Management 50:71-79.

Rogers, D. I., P. F. Battley, T. Piersma, J. A. Van Gils, and K. G. Rogers. 2006. High-tide habitat choice: insights from modelling roost selection by shorebirds around a tropical bay. Animal Behaviour 72:563-575.

Sawyer, H., M. J. Kauffman, and R. M. Nielson. 2009. Influence of well pad activity on winter habitat selection patterns of mule deer. Journal of Wildlife Management 73:1052-1061.

Schummer, M. L., and W. R. Eddleman. 2003. Effects of disturbance on activity and energy budgets of migrating waterbirds in south-central Oklahoma. Journal of Wildlife Management 67:789-795.

Sparling, D. W., and G. L. Krapu. 1994. Communal roosting and foraging behaviour of staging sandhill cranes. Wilson Bulletin 106:62-77.

Stafford, J. D., A. K. Janke, M. J. Anteau, A. T. Pearse, A. D. Fox, J. Elmberg, J. N. Straub, M. W. Eichholz, and C. Arzel. 2014. Spring migration of waterfowl in the northern hemisphere: a conservation perspective. Wildfowl(Special issue) 4:70-85.

Sunde, P., M. S. Bolstad, and K. B. Desfor. 2003. Diurnal exposure as a risk sensitive behaviour in tawny owls Strix aluco? Journal of Avian Biology 34:409-418.

U.S. Fish and Wildlife Service. 1981. The Platte River ecology study. U.S. Fish and Wildlife Service Research Report, Jamestown, North Dakota, USA.

Wheeler, R. H., and J. C. Lewis. 1972. Trapping techniques for sandhill crane studies in the Platte River Valley. U.S. Department of Interior, U.S. Fish and Wildlife Service Resource Publication 107, Washington, D.C., USA.

Zharikov, Y., and D. A. Milton. 2009. Valuing coastal habitats: predicting high-tide roosts of non-breeding migratory shorebirds from landscape composition. Emu 109:107-120.

\section{Associate Editor: Bill Block.}

\section{SUPPORTING INFORMATION}

Additional supporting information may be found in the online version of this article at the publisher's website. 